Jolanta Sajdera

Uniwersytet Pedagogiczny w Krakowie

E-MAIL: jolasaj@gmail.com

\title{
Pułapki w konstruowaniu problemów badawczych z perspektywy doświadczeń badacza edukacji
}

\section{STRESZCZENIE}

Podjęty temat dotyczy sposobów konstruowania problemów badawczych w strategii badań jakościowych nad edukacją. Celem tekstu jest wskazanie możliwości zastosowania koncepcji konstruktów myślowych Alfreda Schütza podczas wyznaczania przez badacza obszaru problemowego, ujętego w strukturę pytań pierwszego i drugiego stopnia. Przywołane założenia teoretyczne problematyzowania celu badań posłużyły do opracowania przedmiotu refleksji - zjawiska pułapki w podejmowaniu decyzji badawczych. Pozwoliły też na rozważenie korzyści z doświadczenia pułapki jako punktu zwrotnego w praktyce badacza.

SŁOWA KLUCzowE: problemy badawcze, Alfred Schütz, konstrukt myślowy, Anselm Strauss, punkt zwrotny

\section{Wprowadzenie}

Rozważania podjęte w artykule odnoszą się do kluczowego elementu projektowania badań naukowych, jakim jest konstruowanie problematyki badawczej. Wychodzę z założenia, że elastyczność projektu badawczego, jako jedna z właściwości badań jakościowych, o której, za M. Pattonem, pisał Dariusz Kubinowski (2016, s. 8), nie wyklucza istnienia pewnych stałych elementów $\mathrm{w}$ postępowaniu badawczym. Jednym $\mathrm{z}$ nich jest wyznaczenie obszaru problemowego, w jakim ma zamiar poruszać się badacz, przez wskazanie celu badań, a następnie ujęcie go w postać pytań/problemów badawczych.

Ze względu na szeroki obszar zagadnienia, skoncentrowałam się na postawieniu pytania o to, w jaki sposób unikać pułapek podczas konstruowania pytań badawczych w strategii badań jakościowych nad edukacją?

$\mathrm{W}$ celu znalezienia odpowiedzi przywołałam najpierw założenia teoretyczne, dotyczące konstruowania pytań badawczych, więcej miejsca poświęcając idei konstruktów myślowych Alfreda Schütza (2008). Następnie odniosłam się do własnej praktyki badawczej, wskazując przykłady pułapek, jakie 
starałam się omijać przygotowując strategię badań. Zwróciłam także uwagę na skutki doświadczenia pułapki przez badacza, nawiązując do koncepcji punktów zwrotnych Anselma Straussa (2013).

\section{Formułowanie pytań badawczych w procedurze badań jakościowych}

Koncepcyjna praca nad problemem badawczym jest rodzajem działalności intelektualnej, którą można przyrównać, zdaniem Schütza (2008), do teoretycznego aktu kontemplacji podejmowanego przez badacza. Twórca socjologii fenomenologicznej opisał dążenie do „rozwiązania w myśli problemu naukowego" w kategoriach działania ukrytego, a jednak intencjonalnego, nakierowanego na przekształcenie „Zamysłu” w cel, a projektu w zamiar jego zrealizowania (s. 20). Wprowadzenie terminu „projekt”, w odniesieniu do aktywności badawczej, otwiera pole znaczeniowe, w którym mieszczą się takie określenia, jak, na przykład: plan, szkic, zarys, opis, proces, problem, opracowanie, konstruowanie, scalanie, przekształcanie. Stanowią one nie tylko wyrazy bliskoznaczne, ale służą teoretykom do wyjaśniania kolejnych etapów procedury badawczej. Ilustracją tego spostrzeżenia są przykłady definiowania procesu stawiania problemów badawczych w literaturze metodologicznej, zawierające sformułowania: „eksplorowanie” (Creswell, 2013, s. 147), "generowanie” (Silverman, 2007, s. 32), „ogniskowanie” (Lofland i in., 2009, s. 171), „(..) problematyzowanie, konkretyzowanie, rozbijanie tematu na mniejsze cząstki” (Kubinowski, 2011, s. 274), „przekształcenie tych ledwie zarysowanych problemów w konkretne pytania (...)" (Hammersley i Atkinson, 2000, s. 40).

Koncepcyjna praca badacza nad wyłanianiem pytań badawczych rozpoczyna się często od etapu swobodnej ekspresji pomysłów. Stopniowo pojawia się jednak konieczność namysłu nad paradygmatem, w jakim prowadzone będą badania, oraz wynikającym z niego przedmiotem badań. Podjęcie decyzji o wyborze paradygmatu nomotetycznego lub idiograficznego nie może być wyborem przypadkowym czy podyktowanym 'modą' na ilościowe/jakościowe podejście. Zdaniem Doroty Klus-Stańskiej (2016), obecny status sporów paradygmatycznych dotyczy określania złożoności świata społecznego ('wielości światów', jak pisał Schütz), który wymaga także różnorodnych podejść badawczych, a więc „współmierności i niewspółmierności paradygmatów” (s. 51). Podjęta przez badacza decyzja o wyborze paradygmatu uwidacznia się w przyjętych ramach pojęciowych, które Matthew B. Miles i Michael Huberman (2000) przyrównują do pojemników zawierających „podstawowe sprawy, które zostaną zbadane - główne czynniki, pojęcia/konstrukty czy zmienne oraz zakładane relacje między nimi” (s. 19). Podczas wyznaczania przez bada- 
cza ram pojęciowych w podejściu idiomatycznym krystalizuje się specyficzna forma pytań badawczych, charakterystycznych dla badań jakościowych. Wynika ona $\mathrm{z}$ koncentracji na jednostkowych doświadczeniach, stanowiących przedmiot badań. Budowanie pytań badawczych jest związane z dążeniem do zrozumienia wyłaniających się aspektów świata przeżywanego przez podmiot, a więc, jak określił Steinar Kvale (2004, s. 43), uzyskania odpowiedzi, „dlaczego podmioty przeżywają i działają tak, jak to się dzieje?”. Z tego względu pytania badawcze w podejściu jakościowym odnoszą się wprost do przedmiotu badań, a więc tego, „jak” opisują świat przeżywany osoby/podmioty/aktorzy społeczni i ,jakie" nadają mu znaczenie (Kostera, 2008, s. 17).

\section{Konstrukty myślowe zawarte w pytaniach badawczych}

Kolejne etapy pracy koncepcyjnej nad pytaniami badawczymi prowadzą badacza do opisania i zrozumienia świata przeżywanego aktorów społecznych. W tym celu odnosi się do kontekstu społecznego, podejmując próbę odkrycia różnorodnych sposobów, w jakich osoby „wytwarzają ową rzeczywistość społeczną" (Schütz, 2008, s. 14).

Opracowany przez Schütza model tworzenia pojęć naukowych stanowić może narzędzie dla wyznaczenia hierarchii znaczeniowej pytań badawczych. Poprzez operowanie „naukowymi obiektami myślowymi”, nazywanymi też przez Schütza „mentalnymi konstruktami” (s. 10), poszerza się rozumienie przez badaczy „wielości światów” osób badanych. Autor charakteryzuje konstrukty pierwszego i drugiego stopnia jako kolejne etapy odkrywania typowych i unikatowych wzorów działania w rzeczywistości społecznej. Wychodząc z tego założenia, można przyjąć, że pytania badawcze I stopnia odnosić się będą do konstruktów potocznych - subiektywnych elementów działania osoby z jej punktu widzenia, doświadczania obiektów i zdarzeń, na przykład: jakie doświadczenia są udziałem...?

Z kolei pytania badawcze II stopnia odnosić się będą do konstruktów tworzonych przez badacza podczas interpretacji konstruktów potocznych. Podstawą konstruowania stają się teoretyczne układy odniesienia (konstrukty kontstruktów; Schütz, 2008, s. 11), wynikające z wiedzy badacza o budowaniu znaczeń przez ludzi. Przykładem mogą być pytania o znaczenie, na przykład: Jakie znaczenia nadają... podmioty... doświadczeniu...?; albo pytania o kontekst, na przykład: jak można zinterpretować znaczenia nadawane przez podmiot... doświadczeniom...?, w jakich obszarach... podmiot doświadcza...?, jak ujawnia się...?, jaki jest kontekst...?

Analizując literaturę metodologiczną, można zauważyć, że badacze posługujący się koncepcją Schütza używają także określenia „pytania/perspektywy 
pierwszorzędowe i drugorzędowe”. Można także odnaleźć ideę konstruktów w proponowanym kierunku budowania pytań badawczych od ogólnych do szczegółowych oraz od opisowych do rozumiejących. Na przykład Martyn Hammersley i Paul Atkinson (2000, s. 42) ukazują kolejność konstruowania pytań badawczych od tworzenia listy zagadnień, które wymagają zbadania, po wyodrębnianie dwóch typów problemów: ogólnych (formalnych) i topicznych (substancjalnych), podkreślając, że nie są one statyczne, ale mogą dynamicznie się zmieniać w trakcie realizacji projektu badawczego.

Zaprezentowane założenia konstruowania pytań badawczych w podejściu jakościowym stały się dla mnie punktem odniesienia dla wyłonienia pułapek, które starałam się omijać, przygotowując własny projekt badawczy.

\section{Pułapka, i jak w nią nie wpaść}

Drugim krokiem budowania odpowiedzi na postawione we wprowadzeniu pytania jest zwrócenie uwagi na pułapki, związane z problematyzowaniem celu badań, podczas stawiania pytań badawczych. Definicja słownikowa pojęcia „pułapka” określa ją jako:

(...) miejsce, w którym ktoś niespodziewanie przekonuje się, że nie może się z niego wydostać lub, przez znajdujące się na nim utrudnienia, bezpiecznie poruszać się po nim (por. Inny SŁownik JęZyka Polskiego, 200o, s. 397).

Odwołując się do tak sformułowanego pojęcia, wyłoniłam trzy rodzaje pułapek, które odniosłam do własnych doświadczeń badacza.

Pierwsza pułapka dotyczy sytuacji, kiedy znajdujemy się w miejscu, którego się nie spodziewaliśmy. Kiedy zaczęłam interesować się podejściem jakościowym w prowadzeniu badań, znalazłam się w miejscu, wktórym, paradoksalnie, poprzednie doświadczenia badawcze mogły otworzyć drogę do wejścia w pułapkę.

W moim przypadku chodziło o wypróbowany w trakcie pracy doktorskiej sposób realizacji strategii badań ilościowych. Celem badawczym procedury badań było prześledzenie związku pomiędzy wyznacznikami rozwoju społecznego (pozycja socjometryczna) a sprawnościami poznawczymi (operowanie obrazami umysłowymi) dzieci w wieku przedszkolnym (Sajdera, 2003, s. 6). Schemat badań służył zweryfikowaniu teorii, z której wyprowadzałam przedzałożenia w postaci hipotez, dobrałam zmienne i kategorie badawcze. Schemat badań miał postać quasi-eksperymentu, obejmując dwie grupy porównawcze dzieci $\mathrm{w}$ wieku przedszkolnym o różnym statusie socjometrycznym (Sajdera, 2003, s. 76). Konstrukcja pytań badawczych była typowa dla modelu opisowo-indukcyjnego, w którym charakterystyczne są pytania 
dotyczące zależności między kontrolowanymi zmiennymi (Creswell, 2013, s. 154). Na przykład mogą mieć formę: "jak częstym zjawiskiem jest..., jaki wpływ..., jakim stopniu...? (opisowe) lub formę: „czy...?” (indukcyjne). Jako (wówczas) młody badacz miałam poczucie panowania nad danymi, które wynikało z kontrolowana zmiennych za pomocą precyzyjnie dobranych technik i narzędzi. W trakcie interpretacji wyników badań dążyłam do wykrycia związków między zmiennymi, co zakończyło się powodzeniem, szczególnie w sytuacji opracowań statystycznych. Przedstawiona powyżej w zarysie procedura badań jest przykładem podejścia empirycznego, prowadzącego do wyjaśnień nomotetycznych, związanych z weryfikowaniem teorii (Rubacha, 2008, s. 20).

Przystępując do realizacji kolejnego projektu badawczego, związanego z opisaniem i zrozumieniem doświadczeń osób dorosłych, zrozumiałam, że badanie „świata przeżywanego" (Schütz, 2008, s. 192) wymaga innego podejścia. Przyjęłam, że celem procedury będą wyjaśnienia idiograficzne, ze względu na subiektywną wyjątkowość ludzkich doświadczeń. Wybrałam postępowanie indukcyjne, jako drogę poznania naukowego, a więc rozpoczęłam od uogólnionego zdefiniowania zjawiska, które mnie zainteresowało. Ograniczyłam wstępne założenia, co do założeń i rezultatów badań, poszukując kategorii teoretycznych w zebranym podczas wywiadów materiale badawczym, a następnie uzasadnień w teorii (indukcja analityczna wywodzona z socjologii humanistycznej Floriana Znanieckiego, np. Silverman 2007, s. 257). Starałam się nie tyle oderwać od ilościowej procedury badawczej, co wykorzystać umiejętności nabyte podczas prowadzenia i interpretowania rozmów kierowanych $\mathrm{z}$ dziećmi do opracowania procedury wywiadu jakościowego z osobami dorosłymi. Uznałam, że nadrzędnym problemem badawczym będzie odpowiedź na pytanie, o to, jakie doświadczenia są udziałem osób badanych, znajdujących się w określonym kontekście społecznym? Zrozumiałam, że nie jestem w stanie przewidzieć, jakie uzyskam dane w efekcie postawienia otwartego pytania badawczego, a co za tym idzie, do jakich wniosków dojdę. I to stało się dla mnie wyzwaniem.

Drugi składnik, przytoczonej powyżej definicji pułapki, dotyczy mylnego przekonania, że jest się w miejscu, z którego nie można się wydostać. To uwikłanie może dotyczyć celowego ograniczania własnych zainteresowań badawczych do (pozornie) znanego kręgu tematycznego czy obszaru badań. Konstruując habilitacyjny pomysł badawczy nie przypuszczałam, że będę blisko wpadnięcia w pułapkę, o jakiej pisał Hammersley i Atkinson (2000, s. 41), a więc sytuacji, w której problem badawczy zostaje sformułowany na podstawie błędnych założeń. 
Ze względu na moje zainteresowania badaniem interakcji społecznych, chciałam nadal poświecić się tej problematyce, starając się jednocześnie, by badania miały wymiar, cytując samą siebie, „bardziej pedagogiczny niż psychologiczny". Tkwiłam wówczas w przekonaniu, że, jako pedagog, muszę być przypisana tylko do określonego aparatu pojęciowego w celu jednoznacznego określenia własnej tożsamości badawczej.

Obecnie mam świadomość, że zamknięcie się w „jedynie słusznej” perspektywie postrzegania rzeczywistości prowadzi donikąd. Ugruntowała mnie w tym przekonaniu lektura publikacji INTERDYSCYPLINARNIE O INTERDYSCYPLINARNOŚCI. MIĘDZY IDEĄ A PRAKTYKĄ, a szczególnie rozdział Joanny Rutkowiak, która pisze o „...względności granic dyscyplin naukowych” (Rutkowiak, 2012, s. 199). Autorka opisuje własną drogę rozwoju badacza z perspektywy relacji międzydyscyplinarnych (psychologia, filozofia, ekonomia) jako skoki, które pomogły jej formułować pytania wychodzące „...poza drogi już wypróbowane...” (s. 220). Jak wynika z lektury tekstu autorki, nie jest łatwo wyjść z samoograniczenia poznawczego bez odwagi szukania odpowiedzi poza tym, co znane.

Z perspektywy czasu rozumiem, że w moim przypadku obawa wyjścia poza dobrze znany krąg badań placówki oświatowej ograniczała moje poszukiwania badawcze. Zdecydowałam się na badanie „wspólnotowości” placówki, nie byłam jednak w stanie określić, jaki problem będę chciała rozwiązać. Przywołany przez Marię Dudzikową David Howarth (Howarth, 2008 za: Dudzikowa, 2012) pisze o „momencie krytycznym” dla badacza, jakim jest problematyzowanie zjawisk. Jest to proces myślowy, który pozwala skonstruować trafnie pytania badawcze. Podczas pierwszej konsultacji „pomysłu na pomysł”, na spotkaniu Zespołu Samokształceniowego Doktorów w 2011 roku w Poznaniu, zaproponowałam następujące pytanie badawcze: „w jaki sposób elementy formułujące wspólnotę można odnaleźć w funkcjonowaniu placówki oświatowej?" Analizując obecnie to pytanie, widzę zarówno błędy semantyczne, jak i brak wewnętrznej zgodności paradygmatycznej. Zbudowanie pytania: „w jaki sposób można odnaleźć elementy...” sugeruje, że takie elementy istnieją, a moim celem będzie jedynie wymyślenie sposobu na ich "odnalezienie". Zastosowanie tego wyrazu w pytaniu sformułowanym inaczej: „jak można odnaleźć elementy formułujące wspólnotę w funkcjonowaniu placówki oświatowej?” wymagałoby uzasadnienia w teorii grup społecznych przebiegu powstawania wspólnoty i wyłonienia elementów (zmiennych) świadczących o przebiegu tego procesu. Kolejnym krokiem byłoby testowanie różnych sposobów szukania wyłonionych elementów (technik kontrolujących zmienne) w celu weryfikowania teorii. 
Tymczasem w pierwotnym pytaniu, poprzez zestawienie takich pojęć, jak: formuła, wspólnota, funkcja, placówka, oświata, z pytaniem otwierającym, „w jaki sposób?”, wprowadziłam chaos znaczeniowy, na co zwróciła mi wówczas uwagę profesor M. Dudzikowa oraz koledzy z Zespołu. Trudno uznać, na podstawie tak postawionego pytania, co miało być przedmiotem badań (elementy? wspólnota? placówka?), kogo (co) planowałam badać i w jakim kontekście. Dążenie do poprawności sformułowania pytania badawczego powinno być poprzedzone zrozumieniem znaczenia używanej terminologii. Konieczne jest zatem zbudowanie problemowych ram pojęciowych, wynikających z przyjętego paradygmatu, o czym pisałam powyżej.

Konsultacje pomogły mi także ominąć jeszcze jedną pułapkę, którą skonstruowałam sama na siebie, polegającą na utrudnieniu bezpiecznego poruszania się w obrębie problemu. W moim przypadku wybranie kategorii „wspólnotowość", stanowić mogło o niepowodzeniu procesu badawczego. Pułapka polegała nie tylko na wyczerpywaniu się „świeżości” kategorii, lecz także na wykazanej mi, w konstruktywnej dyskusji, słabej znajomości tematyki, a co za tym idzie, braku możliwości sformułowania adekwatnych pytań badawczych. Podczas seminarium zrozumiałam, że wiedzę o pojęciu, którym chcę się zająć (w moim przypadku - wspólnotowość), powinnam czerpać najpierw z publikacji twórcy koncepcji (Ferdinand Tönnies) oraz jego następców, zanim sięgnę po przykłady interpretacji przez innych badaczy. Tylko w ten sposób można odkryć znaczenie, jakie nadaje autor własnemu ujęciu zagadnienia. Brak dostatecznej wiedzy o statusie naukowym problemu, czy jest zbadany, w jakim zakresie jest jeszcze nierozwiązany, prowadzić może do stawiania retorycznych pytań badawczych, a zatem wpadnięcia w pułapkę otwierania otwartych drzwi. Także pochopne wskazywanie rozbieżności między tym, co jest, a co powinno, zdaniem badacza, być, prowadzi do pułapki w rodzaju 'samospełniającej się przepowiedni', gdy treść i forma pytań badawczych służy potwierdzeniu własnych przekonań (typowe pytanie „czy i dlaczego...?”).

Sposobem na ominięcie pułapek jest oczywiście stałe poszerzanie wiedzy, znajomość literatury przedmiotu; jednak w moim przypadku także zetknięcie z innym punktem widzenia, konstruktywna krytyka, pomogły mi zrozumieć, w jakim miejscu jako badacz się znajduję. Tak więc uniknęłam sytuacji opisywanej przez Hammersleya i Atkinsona (2000, s. 41), gdy badacz sądzi, że dany problem jest nierozwiązywalny przy obecnym stanie wiedzy, a tak naprawdę chodzi tylko o niewystarczający stan wiedzy badacza. 


\section{Co dalej po wyjściu z pułapki? Konkluzje}

Ominięcie lub wyjście z pułapki nie zamyka rozpoczętych rozważań. Podjęte refleksje skierowały moją uwagę na jeszcze jedno określenie pułapki jako sytuacji, z której trudno wybrnąć. Ilustruje ją stwierdzenie: „czuję się, jak w pułapce”. Postanowiłam zinterpretować to sformułowanie w ujęciu typologii punktów zwrotnych Anselma Straussa (2013), dotyczącej transformacji tożsamości jednostki. Autor zwraca uwagę, że kiedy człowiek podejmuje decyzje, rzadko dostrzega wszystkie ich konsekwencje. Jest to wręcz niemożliwe. Pułapka pojawia się wówczas, gdy okazuje się, że od raz podjętej decyzji nie ma odwrotu, chociaż człowiek sądził, że w każdej chwili może zawrócić $z$ obranej drogi. Jest rodzajem uwikłania przez własne decyzje. Ta sytuacja stanowi punkt zwrotny, definiowany przez Straussa (2013, s. 91) jako moment w rozwoju człowieka, który może prowadzić do ponownego zrewidowania własnych decyzji lub uznania ich za „nostalgiczne wspomnienia”, które nie mogą być już zrealizowane. W przypadku badaczy konsekwencją wpadnięcia w pułapkę może być utrata pracy, konieczność zwrotu funduszy grantowych czy wręcz utrata dobrej opinii w środowisku. Być może warto podjąć badania nad strategiami, jakie podejmowane są $\mathrm{w}$ takich sytuacjach, kiedy trzeba odpowiedzieć sobie na pytanie: „czy naprawdę się na tym znam?”, „czy jest jeszcze czas na zmianę decyzji?”. Uświadomienie sobie bycia w pułapce jest możliwe na każdym etapie prowadzenia badań, jednak sukcesem badacza jest nie tylko unikanie pułapek, ale także wychodzenie $\mathrm{z}$ nich $\mathrm{z}$ coraz lepiej skonstruowanym planem dalszych badań.

Udzielając odpowiedzi na postawione we wprowadzeniu pytanie, przywołałam teoretyczne założenia podejścia jakościowego w konstruowaniu pytań badawczych, a także pokazałam kilka przykładów pułapek. Zdaję sobie sprawę, że nie wyczerpałam wszystkich aspektów problemu, ponieważ skoncentrowałam się wyłącznie na własnych potknięciach. W tym zakresie starałam się także pokazać miejsce, jakie w omijaniu pułapek zajmuje „naukowa wspólnota uczących się" (Bochno i Korzeniecka-Bondar, 2016, s. 11). W moim przypadku stała się nią społeczność gromadzona przez profesor Marię Dudzikową podczas Letnich Szkół Młodych Pedagogów oraz seminariów Zespołu Samokształceniowego Doktorów przy Komitecie Nauk Pedagogicznych PAN. Przebywanie w środowisku, w którym jest „możliwość spotkania i wymiany intelektualnej - dzielenia się poglądami, podejmowania dyskusji i naukowych negocjacji - doświadczania własnej sprawczości" (Bochno i Kopaczyńska, 2014, s. 137), jest moim zdaniem optymalnym rozwiązaniem dylematu pułapki badacza. 
Gdy w jednym z podrozdziałów książki O wiElości światów Schütz analizuje świat teorii naukowej, pisze o wolności myśli teoretycznej, która może być „odwołana” (2008, s. 48) bez wprowadzenia zmian w świecie zewnętrznym. Podążając za refleksjami autora, warto zauważyć, że wolność badacza polega nie tylko na władzy „unicestwienia” własnych poglądów i jednocześnie wytworzenia nowych, ale na dokonywaniu wyboru w sytuacji krytyki, dyskusji, negocjacji, odwagi zaczynania na nowo. Oby każdy badacz był gotowy na tak rozumianą wolność myśli teoretycznej, jak tego chciał Schütz.

\section{BIBLIOGRAFIA}

Bańko, M. (red.). (200o). Inny słownik języka polskiego PWN (t. 2). Warszawa: Wydawnictwo Naukowe PWN.

Bochno, E., Kopaczyńska, I. (2014). Zespół Samokształceniowy i Samopomocy Koleżeńskiej pod patronatem Komitetu Nauk Pedagogicznych PAN - pięciolecie działalności z perspektywy kategorii refleksyjności. Parezja. Czasopismo Forum Młodych Pedagogów przy Komitecie Nauk Pedagogicznych PAN, 2, 127-138.

Bochno, E., Korzeniecka-Bondar, A. (2016). Letnia Szkoła Młodych Pedagogów jako naukowa wspólnota uczących się - wprowadzenie. W: E. Bochno, A. Korzeniecka-Bondar (red.), Naukowa wspólnota uczacych się. XXX-lecie Letniej Szkoły Młodych Pedagogów przy Komitecie Nauk Pedagogicznych PAN (s. 11-24). Białystok: Wydawnictwo Uniwersytetu w Białymstoku.

Creswell, J. W. (2013). Projektowanie badań naukowych. Metody jakościowe, ilościowe i mieszane. Przekł. J. Gilewicz. Kraków: Wydawnictwo UJ.

Dudzikowa, M. (2012). Sytuacja problematyczna interdyscyplinarności w naukach społecznych i humanistycznych (z kryzysem w tle). W: A. Chmielewski, M. Dudzikowa, A. Grobler (red.), Interdyscyplinarnie o interdyscyplinarności. Między idea a praktyka (s. 15-37), Kraków: Oficyna Wydawnicza „Impuls”.

Hammersley, M., Atkinson, P. (2000). Metody badań terenowych. Przekł. S. Dymczyk. Poznań: Zysk i S-ka.

Klus-Stańska, D. (2016). Metodologiczny status badań eklektycznych w pedagogice. Studia $z$ Teorii Wychowania, 2, 45-6o.

Kostera, M. (2008). Antropologia organizacji. Metodologia badań terenowych. Warszawa: Wydawnictwo Naukowe PWN.

Kubinowski, D. (2011). Jakościowe badania pedagogiczne. Filozofia-Metodyka-Ewaluacja. Lublin: Wydawnictwo UMCS.

Kubinowski, D. (2016). Istota jakościowych badań pedagogicznych- wprowadzenie. Jakościowe Badania Pedagogiczne, 1, 5-14. Pozyskano z: https://wnus.edu.pl/jbp, (data dostępu: 15.02.2017).

Kvale, S. (2004). Interviews. Wprowadzenie do jakościowego wywiadu badawczego. Przekł. S. Zabielski. Białystok: „Trans Humana”.

Lofland, J., Snow, D.A., Anderson, L., Lofland, L.H. (2009). Analiza układów społecznych. Przewodnik metodologiczny po badaniach jakościowych. Przekł. A. Kordasiewicz, S. Urbańska, M. Żychlińska. Warszawa: Wydawnictwo Naukowe Scholar.

Miles, M.B., Huberman A.M. (200o). Analiza danych jakościowych. Przekł. S. Zabielski. Białystok: „Trans Humana”.

Rubacha, K. (2008). Metodologia badań nad edukacją. Warszawa: Wydawnictwa Akademickie i Profesjonalne.

Rutkowiak, J. (2012). Moja wędrówka po naukach pomocnych pedagogice. Dynamika praktyki myślenia w tworzeniu obszarów międzydyscyplinarnych. W: A. Chmielewski, M. Dudzi- 
kowa, A. Grobler (red.), Interdyscyplinarnie o interdyscyplinarności. Między idea a praktykq (s. 199-220). Kraków: Oficyna Wydawnicza „Impuls”.

Sajdera, J. (2003). Dziecięce wyobrażenia w kontekście rówieśniczych relacji. Kraków: Wydawnictwo Akademii Pedagogicznej.

Schütz, A. (2008). O wielości światów. Szkice z socjologii fenomenologicznej. Przekł. B. Jabłońska. Kraków: „Nomos”.

Silverman, D. (2007). Interpretacja danych jakościowych. Metody analizy rozmowy, tekstu i interakcji. Przekł. M. Głowacka-Grajper, J. Ostrowska. Warszawa: Wydawnictwo Naukowe PWN.

Strauss, A. (2013). Zwierciadła i maski. W poszukiwaniu tożsamości. Przekł. A. Hałas. Kraków: Nomos.

Żmigrodzki, P. (red.). (2012). Wielki słownik języka polskiego. Pozyskano z: www.wsjpl.pl, (data dostępu: 15.02.2017).

\section{SUMMARY}

\section{The traps in constructing research problems}

from the perspective of education researcher's experiences

This paper explores the process of the construction of research problems in the qualitative research strategy on education. The aim is to indicate the possibility of applying the Alfred Schütz concept of mental constructs during the determining the research problem area. This concept includes constructs of the first and second degree in the research questions. The theoretical assumptions of problematization were used to develop the object of reflection - the phenomenon of a "trap” in making research decisions. They also allowed the author to consider the benefits of "the trap" experience as a turning point in the researcher's practice.

KEY WORDS: research problems, Alfred Schütz, mental construct, Anselm Strauss, turning point 